\title{
Incunabula and perizonium of Neidium (Bacillariophyta)
}

\author{
David G. MANN ${ }^{1} \&$ Aloisie PouLíčKovÁ ${ }^{2}$ \\ ${ }^{1}$ Royal Botanic Garden, Edinburgh EH3 5LR, Scotland, U.K.; e-mail: d.mann@rbge.org.uk \\ ${ }^{2}$ Department of Botany, Faculty of Science, Palacký University, CZ-771 46 Olomouc, Czech Republic
}

\begin{abstract}
The incunabula and perizonium of a paedogamous Neidium deme (in the $N$. ampliatum species complex) are described in detail using light and scanning electron microscopy. The incunabula contain two types of element, both heavily silicified. At each pole of the ellipsoidal zygote there is a large cap, which almost abuts its twin on either side of the zygote, beneath the gametangial valves. The caps are deeply and widely notched on their 'girdle' sides (i.e. on the sides of the zygote that underlie the gametangial girdle) and the space created by the notches is filled by large, almost triangular incunabular plates. Thus, on each side of the equator of the zygote there is one cap element and two plate elements. The caps overlap the plates and must precede them ontogenetically, creating a polarity opposite to that of the transverse perizonium. Both elements are sparsely and irregularly porous and have fimbriate margins. During auxospore expansion, the two sets of incunabular elements separate at the equator of the cell and the transverse perizonium is formed beneath, the incunabula continuing to form a tight seal around the perizonium and apparently constraining development to form a linear tube. All transverse perizonial bands possess delicate fimbriae and are open, even the primary band, which is slightly wider than the bands on either side and bears a median ridge. The open ends of the secondary bands sweep strongly towards the centre of the auxospore, producing a very obvious and wide suture. In expanded auxospores, a robust longitudinal band is found beneath the suture, which has coarser fimbriae than the transverse bands. Possible interpretations of the incunabular elements are discussed: no structures similar to the incunabular plates have been described in other diatoms, but it is known that related genera (Biremis, Muelleria) also have large cap-like elements in their incunabula. The open nature of the primary transverse perizonial band is unusual in raphid diatoms, but auxospore coverings have been investigated ultrastructurally in too few diatoms to permit detection of evolutionary trends.
\end{abstract}

Key words: auxospores, Bacillariophyta, diatoms, incunabula, Neidium, perizonium

\section{Introduction}

Auxosporulation is the process, usually associated with meiosis and sexual reproduction, by which diatoms restore maximum cell size after slow reduction in cell size during the diploid vegetative phase of the life cycle (Round et al. 1990). The development of shape during expansion of the auxospore is controlled by the morphogenesis of the auxospore wall (MANN 1994). In many centric diatoms this morphogenesis is simple, the wall maintaining a homogeneous composition throughout expansion, which is therefore isodiametric. The frustules derived from such auxospores have circular valves. In other centric diatoms and almost all pennate diatoms, however, the auxospore wall expands unequally, producing elongate or multipolar shapes. In most cases investigated so far, the structural heterogeneity producing this unequal expansion involves formation of orderly series of silica bands comprising a 'perizonium' or 'properizonium' (Round et al. 1990), but in a few cases silica bands appear to be absent (e.g. Williams 2001, ManN et al. 2003) and shape is created through differential expansion within a wholly organic wall.

Perizonia are found in pennate diatoms. The first two to be described in detail - in Rhabdonema and Rhoicosphenia - have a similar structure, comprising many transverse bands overlapping each other from the centre (where there is a single symmetrical 'primary' transverse perizonial band) towards the poles of the auxospore, and a much smaller number (five) of longitudinal bands, which again overlap each other from the central band outwards (von STOSCH 1962, 1982; MANN 1982). The transverse series is formed sequentially and in opposite directions simultaneously (from the primary band outwards), creating the elongate shape of the auxospore by progressively 
restricting the area of wall that remains plastically deformable (MANN 1994). In many pennate diatoms, the transverse perizonial bands can be seen in the light microscope as regular thickenings of the auxospore wall, but longitudinal perizonial bands have rarely been confirmed to be present, probably because they are delicate and enclosed by the transverse series. However, a similar structure to that found in Rhabdonema and Rhoicosphenia has been reported in Amphora (NAGUmo 2003). Two araphid pennate diatoms, Gephyria and Grammatophora, differ from the Rhabdonema model in that a longitudinal perizonium is absent, the equivalent position along the ventral side of the auxospore being occupied by a number of shorter, irregular longitudinal elements (SATO et al. 2004, 2008a). A further araphid pennate diatom, Pseudostriatella, does possess a longitudinal perizonium, though its ontogeny appears to differ from that in Rhabdonema and Rhoicosphenia; its transverse perizonium is also unusual, possessing characteristics that resemble the properizonium of multipolar and bipolar centric diatoms (SАTO et al. 2008b). Some Achnanthes species have a longitudinal perizonium but lack any transverse bands (ToyodA et al. 2005, 2006). Overall, however, too little information is available on too few taxa to allow reconstruction of evolutionary trends in perizonium structure.

In addition to a perizonium, some pennate diatom auxospores also possess silica scales or bands externally, which are produced by the zygote during its transformation into an auxospore, before expansion. These silica elements are parts of the 'incunabula', a term (from the Latin for 'swaddling clothes') introduced by TroвAJo et al. (2006) for the "organic and inorganic components (including silicified elements) of the auxospore wall that surround, cover, or invest the perizonium or properizonium as the auxospore expands". In Rhabdonema and Gephyria, the incunabula contain approximately circular scales, consisting of a central annulus subtending an irregular system of branching ribs (VON STOSCH 1982; SATO et al. 2004), whereas in Nitzschia (Trobajo et al. 2006) and Pinnularia (PoulíčKová et al. 2007) there are narrow plain strips of silica, orientated approximately at right angles to the axis of the auxospore.

Allogamous auxosporulation of Neidium was first reported by GRIFFITH (1855) and described in detail for the $N$. ampliatum (EHRENB.) Krammer species complex by MANN (1984) and Mann \& Chepurnov (2005). Paedogamous auxosporulation of a different $N$. ampliatum-like diatom was reported by PoulíčKová (2008a). Her studies focused on nuclear and chloroplast changes during sexual reproduction and auxosporulation, but also briefly documented the presence of silicified caps covering the auxospore poles and the structure of the perizonium as detectable in the light microscope. Here we document the ultrastructure of the incunabula and perizonium in the same paedogamous Neidium clone (NEI140) as was studied by PoulíčKOvá (2008a).

\section{Material and Methods}

Neidium cf. ampliatum was collected from the oligotrophic Loch Achray, Scotland (UK National Grid Reference NN 506068; 77.1 ha) on 29 September 2005. Surface sediments containing $N$. cf. ampliatum and overlying water were collected from lakes using a glass tube, as described by Round (1953), transported to the laboratory in polyethylene bottles, poured out into plastic boxes, and allowed to stand in the dark for at least $5 \mathrm{~h}$. Then the supernatant was removed by suction and the mud covered with lens tissue. Under continuous low-level illumination (c. $5 \mu \mathrm{mol}$ photons $\mathrm{m}^{-2} \mathrm{~s}^{-1}$ ), epipelic algae moved up through the lens tissue and became attached to cover-slips placed on top. Neidium clone NEI140 was isolated by streaking harvested epipelon onto 2\% agar-solidified WC medium (GUILLARD \& LORENZEN 1972) and subculturing from a discrete colony after $c$. 2 weeks. Cells were transferred to liquid WC medium and grown in $50-\mathrm{mm}$ Petri dishes. Incubated cover-slips and stock cultures were kept at $16-18^{\circ} \mathrm{C}$, with 5-20 $\mu \mathrm{mol}$ photons $\mathrm{m}^{-2} \mathrm{~s}^{-1}$ from cool-white fluorescent tubes and usually $12: 12 \mathrm{~h}$ L:D.

To prepare material for light microscopy (LM) or scanning electron microscopy (SEM), 13-mm diameter cover-slips were placed at the bottom of Petri dishes containing culture medium, before the medium was inoculated with the clone. Cover-slips became colonized by cells and were removed 9 or 10 days after inoculation and examined after careful cleaning of the lower side. Cleaned valves and auxospores were prepared in situ by placing the cover-slips on a ceramic hot-plate, adding enough $70 \%$ nitric acid (SEM) or hydrogen peroxide (LM) to produce a domed meniscus covering the whole slip, and evaporating gently to dryness at c. $60^{\circ}$. After a wash with deionized water, LM preparations were made by mounting cover-slips in Naphrax (Brunel Microscopes, Chippenham, U.K.). For SEM, the nitric acid treatment was repeated and then salts and soluble decomposition products were removed by rinsing the cover-slips twice in deionized water (for the first rinse, the deionized water was allowed to stand 
on the cover-slips for at least $10 \mathrm{~min}$ ). After drying, the cover-slips were attached to aluminium stubs by carbon tabs, with silver dag painted around the edges to promote electrical conduction. Stubs were coated with platinum for $2 \mathrm{~min}$ in an Emitech K575X sputter coater and examined using a LEO Supra 55VP Field Emission SEM operated at 5 or $8 \mathrm{kV}$ (4 mm working distance; aperture $20 \mu \mathrm{m}$ ). Images (8-bit or 16-bit grayscale) were captured as $2048 \times 1536$ or $3702 \times$ 2304 pixel TIFF files.

LM photographs were taken using the methods and instrumentation described by PoulíčKOvÁ (2008a).

\section{Results}

Outline of auxospore development, based on LM observations. The morphological and cytological characteristics of Neidium cf. ampliatum clone NEI140 have been described by PouLíčKOVÁ (2008a). Briefly, it has linear valves with rostrate poles (Fig. 1) and 24-27 striae in $10 \mu \mathrm{m}$. During auxosporulation, gametangia $20-46 \mu \mathrm{m}$ long and c. $10 \mu \mathrm{m}$ wide give rise to initial cells of up to $77 \mu \mathrm{m}$ long and c. $14 \mu \mathrm{m}$ wide. During auxosporulation, cells are usually unpaired. Sometimes they may occur in groups like the pairs and larger clusters formed by allogamous Neidium species (cf. Mann 1984; Mann \& Chepurnov 2005), but the association is loose (Fig. 4) and plasmogamy does not occur between gametes formed by different cells. Instead, sexualized cells behave as individuals, going through meiosis (Fig. 4, left cell) and forming two gametes, which become rearranged within the gametangium (Fig. 2 ) and then fuse again to produce a zygote (Fig. 4 , central and right cells). NEI140 is therefore paedogamous. Meiosis, the fate of individual haploid nuclei during gametogenesis, and karyogamy have been documented by PoulíčKovÁ (2008a), using 4',6-diamidino-2-phenylindole (DAPI) staining.

In vegetative and meiotic cells, the protoplast fills the frustule (Fig. 4, left), but the gametes (Fig. 2) do not and nor do the zygotes (Fig. 4, centre and right).The gametes seem to be naked but it is clear, even in living cells, that the zygote possesses a thickened wall (Figs 3, 4). Treatment with oxidizing agents (hydrogen peroxide, nitric acid) removes all the cell contents but leaves the wall of the zygote essentially intact (Fig. 5), because of its high silica content. In LM, the silica component of the zygote wall initially appears to be a single structure (Fig. 5) but is later revealed to consist of two cap-like halves (Figs 9, 10). Subsequently, silica bands are added from the equator outwards (Figs 3, 5) to build up a system of strips (the transverse perizonium) that creates and maintains the linear shape of the auxospore (Figs 8, 9). The strips are apparently all split bands (in LM this is difficult to prove), with their openings aligned along the centre of one side (by convention, the ventral side), forming a suture (Fig. 10). The central band (produced first) is slightly wider than the others and is thickened along its midline, and the narrowest bands are those two to four out from the centre on either side (Fig. 9). In unexpanded zygotes, it is sometimes possible to observe a few approximately transverse silica elements, not only at the centre but also elsewhere (Fig. 6, arrows, Fig. 7), which do not appear to be parts of the transverse perizonium.

During expansion, the tips of the auxospores are covered by caps derived from the zygote wall (Figs 8-10). Once expansion is complete, the initial cell is formed within the auxospore, tight against the perizonium, except at the centre, where the cell contracts slightly (PoulíčKovÁ 2008a, fig. 2W). The initial epivalve is formed on the side opposite to the suture of the transverse perizonium.

Incunabula. As explained previously, incunabula are components of the auxospore wall external to the perizonium, which partly or completely cover the perizonium as the auxospore expands. Examination of unexpanded but mature zygotes (Fig. 11, equivalent to the centre and right cells in Fig. 4) reveals that the whole cell is surrounded by silica elements. However, contrary to the impression given in LM that the zygote wall comprises just two hemiellipsoidal pieces, there are actually six silica elements in the incunabula, viz. two polar caps, and four lateral plates. Covering each pole is a large incunabular cap (Figs 11, 13, $15,16)$, which stretches almost to the centre of each zygote on the sides corresponding in situ to where the zygote is enclosed by the gametangial valves (Figs 11, 13, 14). In contrast, on the sides of the zygote corresponding to the girdle of the gametangium, where the gametangium splits apart to allow expansion of the auxospore, the incunabular caps are deeply notched (arrows, Figs 15 and 16). Filling the gaps left by the cap notches are four large incunabular plates, two on either side, which meet along the equator of the zygote (Fig. 11).

The structure of the caps and plates 


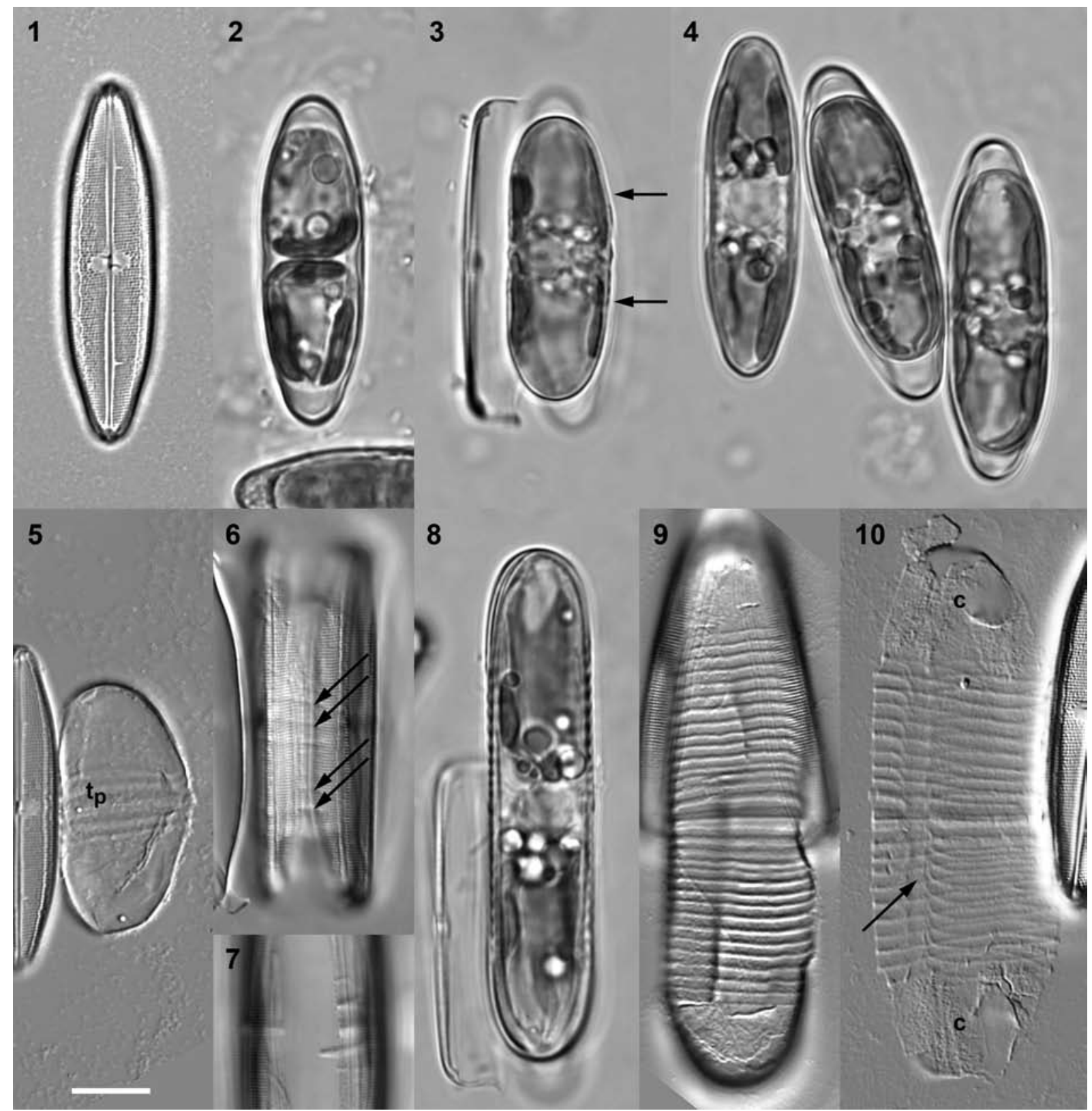

Figs 1-10. Neidium cf. ampliatum, clone NEI140, LM (Figs 1-4, 8, bright field optics; Figs 5-7, 9 and 10, differential interference contrast): (1) Cleaned valve; (2) Gametes in unpaired gametangium; (3) Early stage in auxospore expansion, with partly formed transverse perizonium (extent marked by arrows); note the empty gametangial theca to the left; (4) A gametangium in meiotic prophase (left) and two cells in which paedogamous fusion has produced an ellipsoidal zygote (centre and right); (5-7) Burnt preparations of young auxospores showing the cap-like incunabula and the first, regularly arranged transverse perizonial bands (Fig. 5; $\mathrm{t}_{\mathrm{p}}$ indicates the primary transverse band), and some irregular thickenings (Fig. 6, arrows) that appear also to be bands (broken ends in Fig. 7); (8) Almost fully expanded auxospore; $(9,10)$ Burnt preparations of expanded auxospores, showing the dorsal (Fig. 9) and ventral (Fig. 10) aspects of the perizonium and incunabular caps (c). On the ventral side, the curved ends of the transverse bands form a suture (arrow). Scale bar $10 \mu \mathrm{m}$.

is similar. Both are sparsely and somewhat irregularly porous, being perforated by a mixture of small round holes and short slits (Fig. 17). On the inside of the caps, the pores are more obvious (Fig. 12). At their margins, both the caps and the plates split into a fringe of flat branches (fimbriae), those on the caps being finer than those on the plates. The presence of 'fans' of fimbriae at the cap edges (Figs 14-17) suggests that silicification may be occurring outwards from a few centres, rather than uniformly along a single front, which could indicate that the cap is derived from fused scales, but no matching pattern can be detected in the distribution of holes and slits within each cap. The caps overlap the plates (Figs 11, 17) and must be produced before them, whereas the two plates 


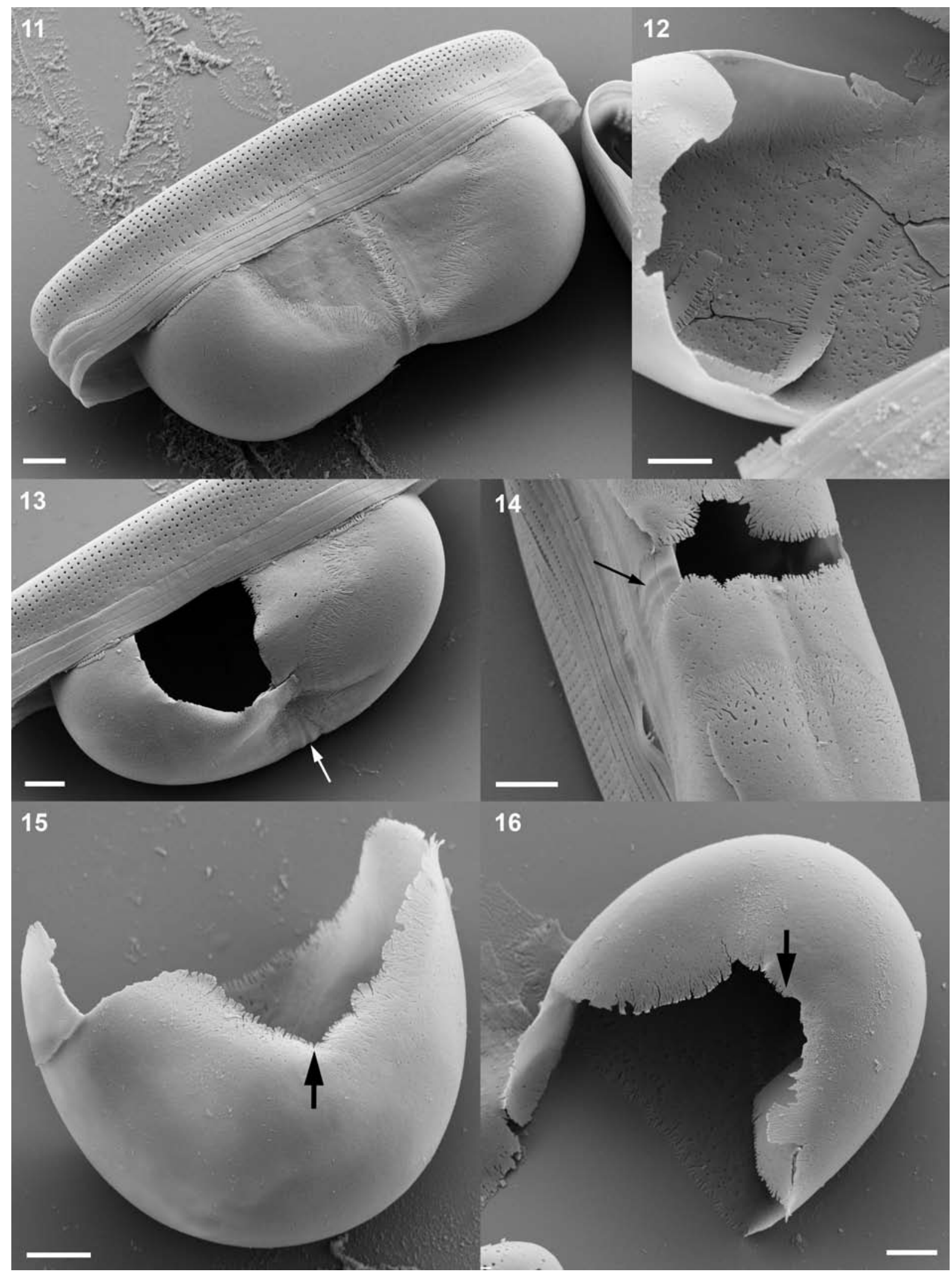

Figs 11-16. Neidium cf. ampliatum, clone NEI140, SEM: (11) Unexpanded auxospore still partially within the gametangial theca, covered by incunabular plates and caps; (12) Broken incunabular cap, interior, showing its irregular pattern of pores and slits (a perizonial band of unknown origin lies across the cap); (13) Unexpanded auxospore in girdle aspect, in which one incunabular plate has been lost. A striated structure is present equatorially (arrow); (14) Thecal aspect of an unexpanded auxospore, showing the close apposition of the incunabular caps on this side; $(15,16)$ Two displaced incunabular caps, each with a V-shaped notch (arrows) which accommodates the incunabular plates. Scale bars $2 \mu \mathrm{m}$. 
on each side of the zygote abut without overlap at the zygote's equator (Fig. 17), consistent with the idea that they are formed simultaneously.

The nature of the extra, irregular bands of silica visible in LM could not be determined. In Figs 13 and 14, transverse bands or thickenings are visible between the incunabular elements, but it is not clear whether these represent the banding seen in LM in Figs 6 and 7, or whether they are broken pieces of the first perizonial bands.

Perizonium. The slight equatorial ridge visible in Fig. 11 probably reflects the presence of the primary transverse perizonial band, already formed beneath the incunabular plates (see also Fig. 17, arrow). The primary band bears a slight median ridge (Figs 20,23) and it is symmetrical, but otherwise it resembles all the other transverse bands in being open and finely fimbriate (Figs $20,21,25)$. The open ends of the secondary transverse perizonial bands curve inwards (Figs $10,20,2125)$ and in the later-formed secondary bands (i.e. those closer to the poles), they taper considerably and sweep far up towards the centre (Fig. 26). Equivalent bands on either side of the centre (second and second transverse bands, third and third, etc) are not connected along the suture: each is a separate entity (Figs 21, 25). As noted in LM, the narrowest bands are usually those close to the centre (Figs 20-23).

As the auxospore expands, the two sets of incunabular elements are separated and carried away from each other at the tips of the auxospore (Figs 18, 19, 23), creating a particularly phallic appearance. The fit between the incunabular elements and the perizonium is tight (Figs 18, $19,23,24)$. The fimbriae of the incunabular plates are noticeably coarser than those of the transverse perizonial bands (Fig. 24). One pole of the auxospore sometimes remains within the gametangium (Fig. 18).

Careful examination of perizonia disrupted by specimen preparation (Fig. 26) or expansion of the initial cell (Figs 21, 25, 27) revealed at least one longitudinal perizonial band lying beneath the suture (therefore on the side where the initial hypotheca is formed). This band is more robust and more coarsely fimbriate than the transverse bands (Figs 26, 27).

In Figs 21 and 25 (of the same cell), an incomplete valve is present beneath the transverse perizonium but apparently outside the longitudinal perizonial band. Whether or not this is autochthonous is unknown and its presence remains unexplained. The final phase of development occurs when the expanding initial cell splits the perizonium and the incunabular plates and caps are jettisoned (Fig. 22).

\section{Discussion}

Incunabula. In Rhoicosphenia, the first raphid diatom in which auxospores were studied in detail with SEM, no incunabular siliceous elements were reported external to the perizonium (MANN 1982) and there appear to be none also in Caloneis ventricosa (Ehrenb.) MeIster (Mann 1989) and Navicula cryptocephala KüTz. (PoulíčKovÁ \& MANN 2006). At least in N. cryptocephala, which was studied using critical point dried specimens from clonal cultures, the absence of silica elements from the incunabula seems to be real. However, the discovery of silicified incunabular strips in Nitzschia fonticola (GRUN.) Grun. (Trobajo et al. 2006) and Pinnularia (PoulíčKovÁ et al. 2007) suggests that Rhoicosphenia and Caloneis should be reinvestigated. KACZMARSKA et al. (2000) showed the presence of small circular scales during auxosporulation in Pseudonitzschia multiseries (HASLE) Hasle and claimed that they were present before plasmogamy on the passive (female) gamete. It would seem curious for gametes to surround themselves with scales, because it might be expected that scales would interfere with plasmogamy. No proof was given that the scaly cells were gametes rather than very young auxospores and it is possible, perhaps, that the scales are formed after fertilization, as part of the incunabula. Unfortunately, no light was shed on this by Амато et al. (2005) or Амато \& Montresor (2008), because the Pseudo-nitzschia species they studied lacked scales altogether.

In a heterothallic deme of Neidium ampliatum (MANN \& ChePURNov 2005), ManN (1984, as 'Neidium affine') demonstrated the presence of silica caps over the ends of the auxospores. It was suggested that the caps "are composite structures, with several centres of mineralization", because LM observations appeared to show irregular rib systems subtended by small annuli, as if each cap were composed of several fused scales. Silicified caps also occur in Biremis (MANN 1993), Muelleria (EDLund \& SpaUlding 2006) and probably in Scoliopleura (ibid.).

The incunabular caps of the heterothallic 


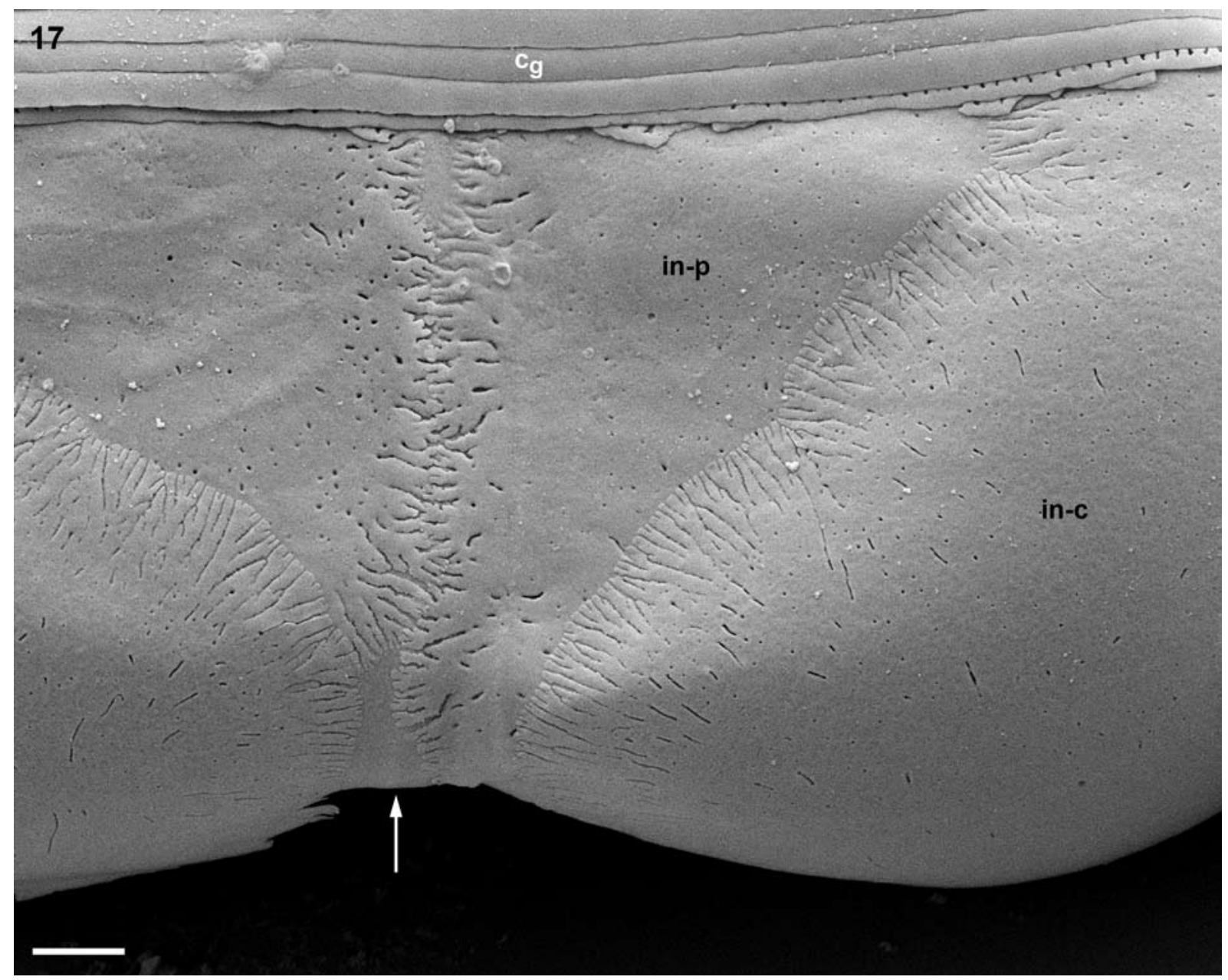

Fig. 17. Neidium cf. ampliatum, clone NEI140, SEM: detail of the centre of the unexpanded auxospore shown in Fig. 11. Note that the incunabular caps (in-c) overlap the incunabular plates (in-p), which in turn overlap an element (arrow) that is probably the primary transverse perizonial band. One side of the auxospore is still contained within the cingulum $\left(\mathrm{c}_{\mathrm{g}}\right)$ of one of the gametangial thecae. Scale bar $1 \mu \mathrm{m}$.

N. ampliatum studied by MANN (1984) appeared in LM to comprise a single hemiellipsoidal element with a scalloped margin. By contrast, the incunabula of NEI140 contain two distinct types of element, caps and plates, of which the latter have no obvious counterpart in any other diatom studied to date. The cap elements overlap the plates and must be formed first. Thus, the polarity shown in the development of the incunabula, from the poles inwards, is opposite to that of the transverse perizonium. No polarity was detected in the other incunabula studied recently by SEM, in Nitzschia fonticola (Trobajo et al. 2006) and Pinnularia (PoulíčKové et al. 2007), though it would be more difficult to detect the direction of overlaps in the systems of narrow strips found in these diatoms.

MANN (1984) considered that, because the caps of Neidium bore the same spatial and temporal relationship to the auxospore and perizonium as the scales of Rhabdonema, the caps were probably "homologous with the scales of Rhabdonema and centric auxospores", but that "electron microscopy will be necessary to determine to what extent the homology is reflected in structure as well as position." Our observations cast some doubt on MANN's view. The polarized development of the incunabula in NEI140 contrasts with the primary scale cases of centric diatoms and Rhabdonema, where the scales are spread more or less evenly over the young auxospore, becoming unequally distributed only as a consequence of anisometric development of the auxospore beneath the scale case, e.g. in Chaetoceros didymum Schussnig or Odontella (von Stosch 1982) or Gephyria (SАто et al. 2004). However, von Stosch (1982) showed that in some centric diatoms (e.g. Triceratium, Lithodesmium, Bellerochea and Biddulphia) and also in Rhabdonema, the primary case of undifferentiated scales sometimes overlies a 


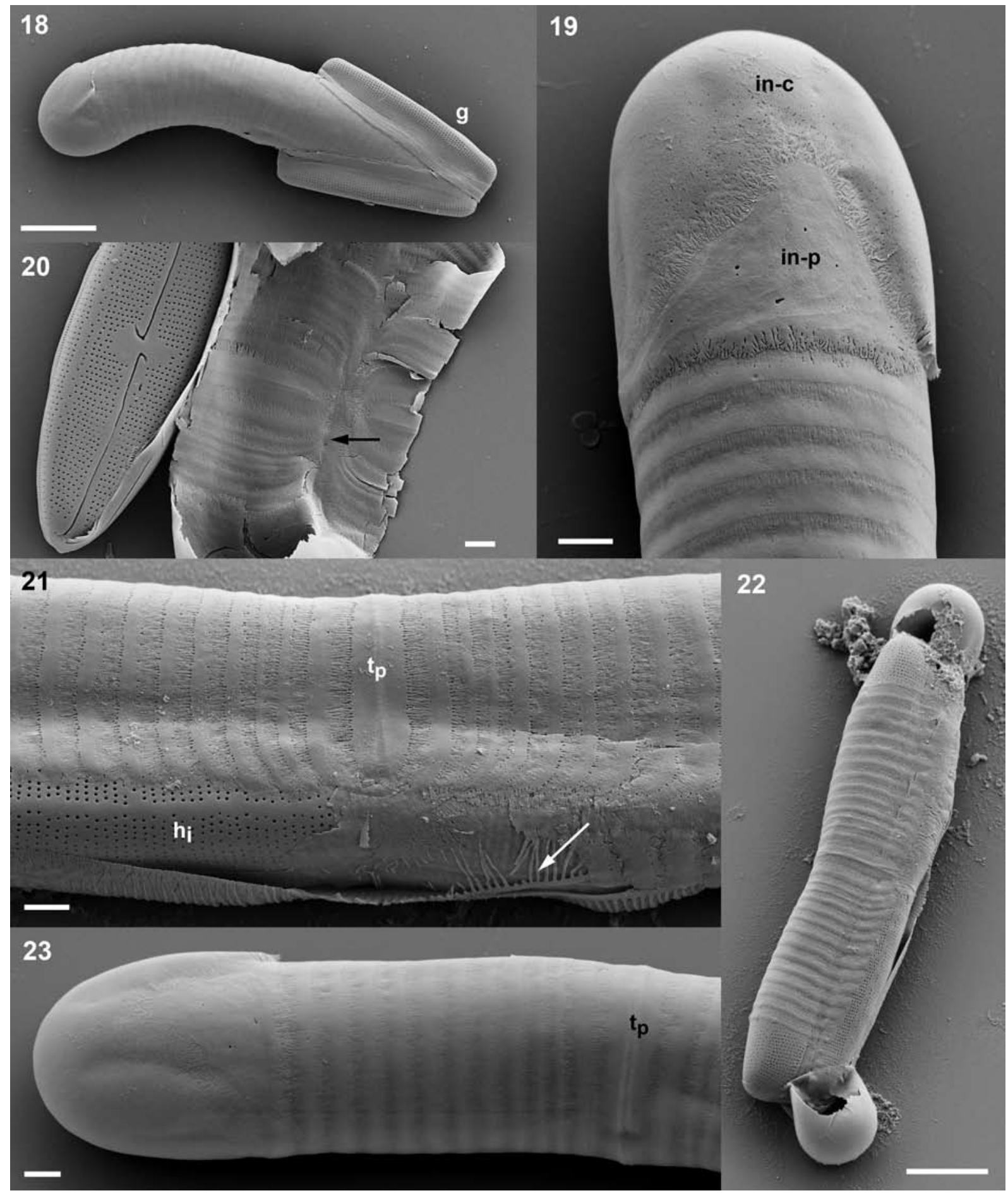

Figs 18-22. Neidium cf. ampliatum, clone NEI140, SEM: (18) Expanding auxospore, with one pole trapped inside the gametangium (g); (19) Auxospore pole, showing the incunabular cap (in-c) and one of the incunabular plates (in-p) fitting tightly over the end of the perizonium (for detail, see Fig. 24); (20) The ventral side of a collapsed auxospore, showing the suture (arrow) and narrow bands either side of the central primary band; (21) Central part of a perizonium stretched by the fully formed initial cell within it. Note the open ends of the transverse perizonial bands, including the primary band $\left(t_{p}\right)$, and the initial hypovalve $\left(\mathrm{h}_{\mathrm{i}}\right)$. The opened suture also reveals an incomplete valve (arrow; see also Fig. 25) consisting only of raphe system and partly formed ribs and a longitudinal perizonial band (see Fig. 27); (22) The whole of the auxospore shown in Fig. 21, with displaced incunabular caps; (23) Half auxospore, dorsal view, showing parallel bands and a slightly differentiated, wider primary band $\left(\mathrm{t}_{\mathrm{p}}\right)$. Scale bars $10 \mu \mathrm{m}($ Figs 18,22$)$ or $2 \mu \mathrm{m}$. 


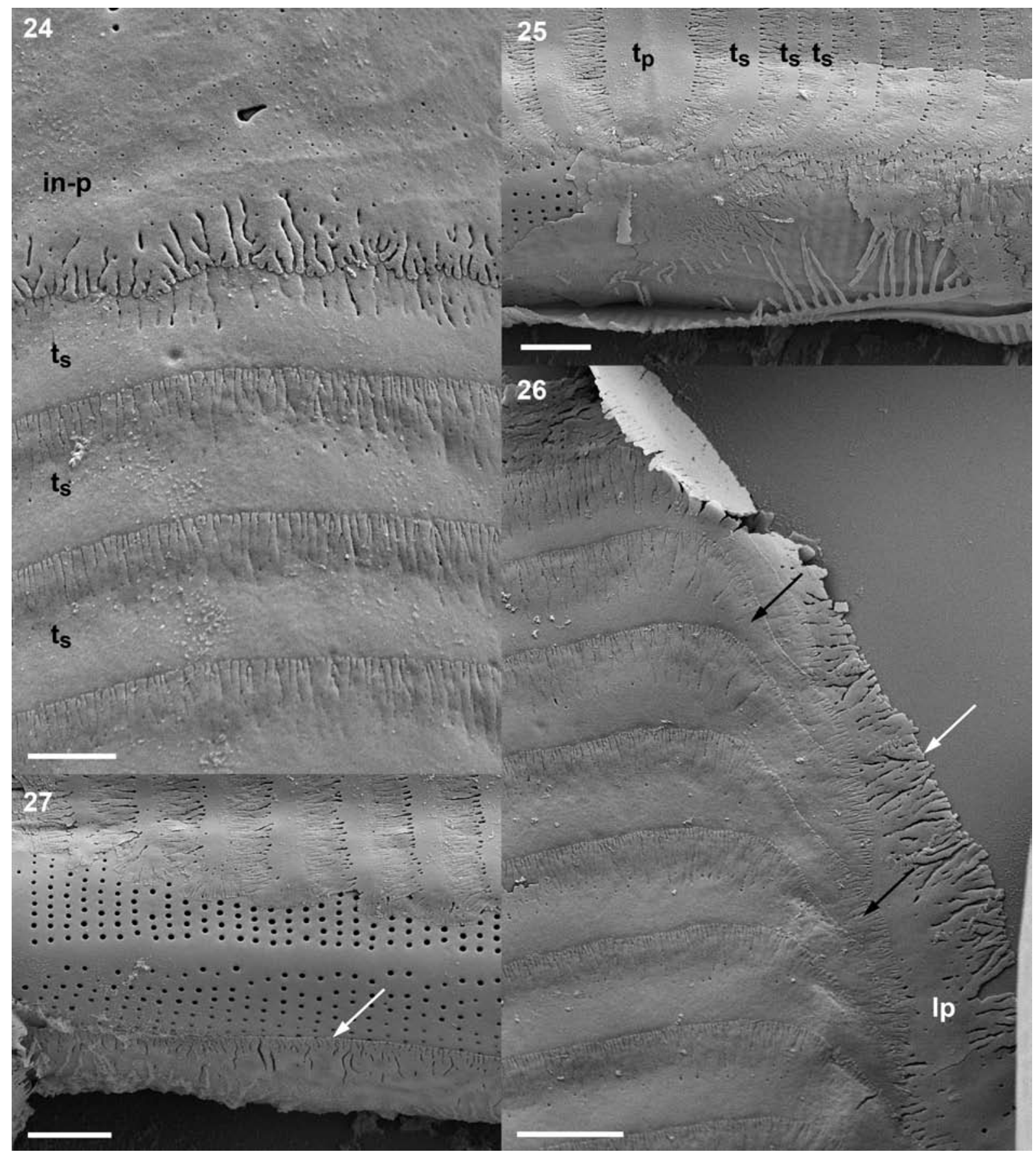

Figs 24-27. Neidium cf. ampliatum, clone NEI140, SEM: (24) Detail of the overlap between an incunabular plate (in-p) and the perizonium ( $\mathrm{t}_{\mathrm{s}}$, secondary transverse perizonial bands); (25) Transverse perizonium: detail of the centre (see also Fig. 21) showing the open ends of the primary and secondary bands $\left(t_{p}\right.$ and $t_{s}$ ). Fragments of longitudinal perizonial elements seem to be present in the suture; (26) Collapsed auxospore case, showing the centripetally swept ends of the transverse perizonial bands (black arrows) and the longitudinal perizonium (lp) with coarse fimbriate margin (white arrow); (27) Part of longitudinal perizonium (white arrow). Scale bars $2 \mu \mathrm{m}$ or $1 \mu \mathrm{m}$ (Fig. 24 only).

somewhat disorderly 'epizonium' of scales, rings or bands, which are apparently concentrated in the areas that become the poles of the auxospore and which von Stosch suggested may protect the growing regions. Conceivably, therefore, the incunabular caps and plates of Neidium may be homologous with the epizonium, rather than with the preceding, undifferentiated primary scale case. However, the Neidium incunabula are not disorderly in their arrangement but positioned precisely in relation to the polarity of the auxospore and gametangium.

ManN (1984) suggested that Neidium uses its silicified caps to control the size of the 
transverse perizonium (creating a parallel-sided tube in which the linear initial cell is produced), since each new transverse band is formed tight against the cap margin. Our new observations (e.g. Figs 19, 23) are consistent with this view. The incunabula may also protect the young zygote. However, both possible functions fail to explain why the caps consist of cap elements and plate elements, instead of cap elements alone. The positions of the plates in NEI140 correspond quite well to the copulation canals through which the gametes move to fertilize each other in allogamous Neidium species (MANN 1984, figs $9-15,28)$. Perhaps, therefore, if plates are also present in allogamous species, they may act to close the copulation canals once plasmogamy is complete, this function becoming redundant in NEI140 because of its paedogamy. SEM studies of allogamous Neidium are needed to check this possibility.

Detailed structure of incunabular and perizonial elements. We could not detect any pattern in the arrangement of the pores and slits in the incunabular caps of NEI140, in contrast to the heterothallic Neidium studied by MaNN (1984). On the other hand, in both demes (which are probably separate species) the caps exhibit scalloped edges, suggesting silicification from discrete centres, rather than uniformly along a single front. Both the caps and the plates have fimbriate edges, thus resembling not only the perizonial bands of various pennate diatoms (e.g. Mann 1982, Sato et al. 2004, 2008a, b; PoulíčKová \& Mann 2006, PoulíčKová et al. 2007) but also the incunabular scales of some other pennate diatoms (e.g. SATо et al. 2004, 2008a, b), and the scales and properizonial bands of centric diatoms (von Stosch 1982). Similar fimbriae are also present around the margins of the valves of vegetative cells in some lightly silicified diatoms, e.g. Fistulifera (Krammer \& Lange-Bertalot 1986, pl. 75, figs 37, 38, as Navicula spp). Round \& CRAWFORD (1981) regarded fimbriate margins as a primitive characteristic, reflecting a supposed common origin of all kinds of silica structures in diatoms - valves, girdle bands and the special silica structures formed during auxosporulation - from the simple radially organized scales around the hypothetical 'pre-diatoms'. Whether or not fimbriae were present from an early stage in diatom evolution, it is clearly true, from their distribution across different lineages of diatoms and occurrence in different stages of the life cycle, that the process of silicification in diatoms readily produces these finely branching structures.

The coarseness and periodicity of branching of the fimbriae varies within NEI140, the fimbriae of the incunabular plates being coarser than those of the caps, which are in turn coarser than those of the transverse perizonial bands (Fig. 19).

Perizonium. MAnN (1984, fig. 22) drew the primary transverse perizonial band of his allogamous Neidium as open, but he gave no electron micrographs and was equivocal in the text about whether the band was open or closed (saying of the transverse perizonium 'All except perhaps the central band are open hoops...'). In NEI140, however, the primary band is quite clearly open and the ventral suture is uninterrupted from pole to pole (Figs 21, 22). Most of the raphid diatoms studied so far have closed primary bands (e.g. CoHN et al. 1989, Mann 1989, Nagumo 2003, PoulíčKovÁ \& Mann 2006, PoulíčKová et al. 2007, PoulíčKová 2008 b), which are sometimes much wider than the transverse bands on either side though not always (MANN 1982). Open primary bands are known from several araphid pennate diatoms, e.g. Rhabdonema (von Sтоsch 1962, 1982), Gephyria, Grammatophora, Pseudostriatella and Tabularia (SATO et al. 2004, 2008a, b, c), but among raphid diatoms they have been reported only from Pseudo-nitzschia multiseries (KACZMARSKA et al. 2000, fig. 8), Neidium (MANN 1984 and this paper), and possibly Cocconeis (Mizuno 1998). Too few taxa have been studied for it to be clear whether closed primary bands have evolved more than once during the diversification of raphid diatoms. Nor is the functional significance of closed and open bands clear. A priori, it would seem likely that closed bands will exert tighter constraints than open bands on the morphogenesis of the auxospore, but will make it more difficult for the initial cell to escape from the perizonium.

The suture of the Neidium perizonium is like most others that have been studied in being marked by a strong centripetal curvature of the ends of the transverse bands. In NEI140 the curvature is particularly strong (see especially Figs 20, 26), compared to Navicula cryptocephala (PoulíčKovÁ \& MANn 2006) or Luticola dismutica (Hust.) D.G.ManN (PoulíčKovÁ 2008b). In Caloneis, there is no curvature and the line of the suture is slightly staggered (MANN 1989).

MANN (1982) found differences between the earlier-formed transverse perizonial bands of Rhoicosphenia and those produced later, the latter 
having more widely spaced, coarser fimbriae. In NEI140, all of the transverse bands have approximately the same fimbria spacing. The development of the fimbriae varies among pennate diatoms, from a wide fringe in Rhoicosphenia (Mann 1982), Pinnularia cf. gibba (PoulíčKovÁ et al. 2007) and Gomphoneis mesta PassY-Tolar \& Lowe (Passy-Tolar \& Lowe 1995), through short stubs in Navicula cryptocephala (PouLíčKovÁ \& MANN 2006), to almost entire margins in Caloneis ventricosa (MANN 1989) and apparently plain and very delicate bands in Pseudo-nitzschia (Kaczmarska et al. 2000, Амato et al. 2005, Amato \& Montresor 2008).

Future prospects. It is increasingly clear that there is much more variation in the auxospore coverings of pennate diatoms than appeared to be the case 25 years ago, when investigations of Rhabdonema (von Stosch 1962, 1982) and Rhoicosphenia (MANN 1982) had demonstrated remarkable similarity in the auxospore envelopes of two very distantly related pennate diatoms. This suggested there might be a common Bauplan for all pennate auxospores and subsequent research has indeed confirmed that the main components present in Rhabdonema (incunabula, transverse perizonium, longitudinal perizonium) do comprise the basic toolbox pennate diatoms have for constructing new enlarged cells. Nevertheless, discovery of the strip incunabula in Nitzschia and Pinnularia (TRoBajo et al. 2006, PoulíčKová et al. 2007), the system of incunabular caps and plates in Neidium, and perizonia in Achnanthes that lack the transverse series of bands (von STOSCH 1982, Toyoda et al. $2005,2006)$ indicate that there is a huge amount still to be discovered about auxospore casings in pennate diatoms, not only in terms of structure but also of ontogeny, evolution and functions.

\section{Acknowledgements}

We thank Frieda Christie for help in preparing specimens and teaching us how to use the LEO Supra; the Royal Society for an equipment grant to purchase a Polyvar photomicroscope; project GACR 206/07/0115 from the Czech Republic; and an EU Framework 6 SYNTHESYS award to Aloisie Poulíčková.

\section{References}

Amato, A. \& Montresor, M. (2008): Morphology, phylogeny, and sexual cycle of Pseudo-nitzschia mannii sp. nov. (Bacillariophyceae): a pseudo- cryptic species within the $P$. pseudodelicatissima complex. - Phycologia 47: 487-497.

Amato, A., Orsini, L., D’Alelio, D. \& Montresor, M. (2005): Life cycle, size reduction patterns, and ultrastructure of the pennate planktonic diatom Pseudo-nitzschia delicatissima (Bacillariophyceae). - J. Phycol. 41: 542-556.

Cohn, S.A., Spurck, T.P. \& Pickett-Heaps, J.D. (1989): Perizonium and initial valve formation in the diatom Navicula cuspidata (Bacillariophyceae). - J. Phycol. 25: 15-26.

EdLund, M.B. \& Spaulding, S.A. (2006): Initial observations on uniparental auxosporulation in Muelleria (Frenguelli) Frenguelli and Scoliopleura Grunow (Bacillariophyceae). In Ognjanova-Rumenova, N. \& Manoulov, K. (eds): Advances in phycological studies: Festschrift in honour of Prof. Dobrina Temniskova-Toplavova. - pp. 213-225, Pensoft Publishers, Sofia and Moscow.

GrifFith, J.W. (1855): On the conjugation of the Diatomaceae. - Ann. Mag. Nat. Hist., ser. 2, 16: 92-94.

Guillard, R.R.L. \& Lorenzen, C.L. (1972): Yellowgreen algae with chlorophyllide c. - J. Phycol. 8: 10-14.

Kaczmarska, I., Bates, S.S., Ehrman, J.M. \& Léger, C. (2000): Fine structure of the gamete, auxospore and initial cell in the pennate diatom Pseudonitzschia multiseries (Bacillariophyta). - Nova Hedwigia 71: 337-357.

Krammer, K. \& LAnge-Bertalot, H. (1986): Bacillariophyceae 1. Teil: Naviculaceae. - In: Ettl, H., Gerloff, J., Heynig, H. \& Mollenhauer, D. (eds): Süsswasserflora von Mitteleuropa, Vol. 2/1. - 876 pp., G. Fischer, Stuttgart \& New York.

ManN, D.G. (1982): Structure, life history and systematics of Rhoicosphenia (Bacillariophyta). II. Auxospore formation and perizonium structure of Rh. curvata. - J. Phycol. 18: 264274.

ManN, D.G. (1984): Auxospore formation and development in Neidium (Bacillariophyta). Br. Phycol. J. 19: 319-331.

MANN, D.G. (1989): On auxospore formation in Caloneis and the nature of Amphiraphia (Bacillariophyta). - Pl. Syst. Evol. 163: 43-52.

ManN, D.G. (1993): Patterns of sexual reproduction in diatoms. - Hydrobiologia 269/270: 11-20.

ManN, D.G. (1994): The origins of shape and form in diatoms: the interplay between morphogenetic studies and systematics. - In Ingram, D.S. \& Hudson, A.J. (eds): Shape and form in plants and fungi. - pp. 17-38, Academic Press, London.

ManN, D.G. \& Chepurnov, V.A. (2005): Auxosporulation, mating system, and reproductive isolation in Neidium 
(Bacillariophyta). - Phycologia 44: 335-350.

Mann, D.G., Chepurnov, V.A. \& IDEI, M. (2003): Mating system, sexual reproduction and auxosporulation in the anomalous raphid diatom Eunotia (Bacillariophyta). - J. Phycol. 39: 1067-1084.

Mizuno, M. (1998): Sexual reproduction and auxospore formation of the marine monoraphid diatom Cocconeis pellucida. - Diatom Res. 13: 103112.

Nagumo T. (2003): Taxonomic studies of the subgenus Amphora Cleve of the genus Amphora (Bacillariophyceae) in Japan. - Bibliotheca diatomol. 49: 1-265.

Passy-Tolar, S. \& Lowe, R.L. (1995): Gomphoneis mesta (Bacillariophyta). II. Morphology of the initial frustules and perizonium ultrastructure with some inferences about diatom evolution. J. Phycol. 31: 447-456.

PoulíčKovÁ, A. (2008a): Pedogamy in Neidium. - Folia Microbiol. 53: 125-129.

PoulíčKová, A. (2008b): Morphology, cytology and sexual reproduction in the aerophytic cave diatom Luticola dismutica (Bacillariophyceae). - Preslia 80: 87-99.

PoulíčKovÁ, A. \& MAnn, D.G. (2006): Sexual reproduction in Navicula cryptocephala (Bacillariophyceae). - J. Phycol. 42: 872-886.

PoulíčKová, A., Mayama, S., Chepurnov, V.A. \& Mann, D.G. (2007): Heterothallic auxosporulation, incunabula and perizonium in Pinnularia (Bacillariophyceae). - Eur. J. Phycol. 42: 367390.

Round, F.E. (1953): An investigation of two benthic algal communities in Malham Tarn, Yorkshire. - J. Ecol. 41: 174-179.

Round, F.E. \& CRAwFord, R.M. (1981): The lines of evolution of the Bacillariophyta. I. Origin. Proc. R. Soc. Lond., B 211: 237-260.

Round, F.E., Crawford, R.M. \& MAnN, D.G. (1990): The diatoms. Biology and morphology of the genera. - 747 pp., Cambridge University Press, Cambridge.

Sato, S., Nagumo, T. \& Tanaka, J. (2004): Auxospore formation and the morphology of the initial cell of the marine araphid diatom Gephyria media (Bacillariophyceae). - J. Phycol. 40: 684-691.
Sato, S., Mann, D.G., Nagumo, T., TAnaka, J., TADANO, T. \& MedLIn, L.K. (2008a): Auxospore fine structure and variation in modes of cell size changes in Grammatophora marina (Bacillariophyta). - Phycologia 47: 12-27.

Sato, S., Mann, D.G., Matsumoto, S. \& Medlin, L.K. (2008b): Pseudostriatella (Bacillariophyta); a description of a new araphid diatom genus based on observations of frustule and auxospore structure and $18 \mathrm{~S} \mathrm{rDNA}$ phylogeny.-Phycologia 47: 371-391.

Sato, S., Kuriyama, K., Tadano, T. \& Medlin, L.K. (2008): Auxospore fine structure in a marine araphid diatom Tabularia parva (Bacillariophyta). - Diatom Res. 23: 423-433

Stosch, H.A. von (1962): Über das Perizonium der Diatomeen. - Vortr. Gesamtgeb. Bot. 1: 43-52.

Stosch, H.A. von (1982): On auxospore envelopes in diatoms. - Bacillaria 5: 127-156.

Toyoda, K., Idei, M., NAgumo, T. \& TAnakA, J. (2005): Fine structure of the vegetative frustule, perizonium and initial valve of Achnanthes yaquinensis (Bacillariophyta). - Eur. J. Phycol. 40: 269-279.

Toyoda, K., Williams, D.M., Tanaka, J. \& Nagumo, T. (2006): Morphological investigations of the frustule, perizonium and initial valves of the freshwater diatom Achnanthes crenulata Grunow (Bacillariophyceae). - Phycol. Res. 54: 173-182.

Trobajo, R., Mann, D.G., Chepurnov, V.A., Clavero, E. \& Cox, E.J. (2006): Auxosporulation and size reduction pattern in Nitzschia fonticola (Bacillariophyta). - J. Phycol. 42: 1353-1372

Williams, D.M. (2001): Comments on the structure of 'post-auxospore' valves of Fragilariforma virescens. - In: JAHN, R., KociOLEK, J.P., Witkowski, A. \& Compère, P. (eds): LangeBertalot Festschrift. - pp. 103-117, A.R.G. Gantner, Ruggell, Liechtenstein.

(C) Czech Phycological Society

Received April 30, 2009

Accepted May 15, 2009 